\title{
Effectiveness of acupuncture for temporomandibular disorders and associated symptoms
}

\author{
Eficiência da acupuntura no tratamento das disfunções temporomandibulares e sintomas \\ associados
}

Thânia Orlando Garbelotti ${ }^{1}$, Andressa Mendonça Turci ${ }^{1}$, Julia Maria V. do Amaral Serigato' ${ }^{1}$ Karina Eiras Dela Coleta Pizzol ${ }^{1}$, Ana Lúcia Franco-Micheloni ${ }^{1}$

DOI 10.5935/1806-0013.20160076

\section{ABSTRACT}

BACKGROUND AND OBJECTIVES: Temporomandibular disorder is defined as a set of clinical problems involving masticatory muscles, temporomandibular joint and associated structures. For having multifactorial etiology, several treatments are proposed and successfully used. However, most recommended therapies are those reversible and noninvasive, which should be the first choice to treat temporomandibular disorders. This study aimed at discussing acupuncture to treat temporomandibular disorders and associated symptoms.

CONTENTS: This is a review of 34 articles published between 1983 and 2015. Since acupuncture aims at returning balance to body and harmony between physical and psychical parts by stimulating specific points, it may be considered therapy of choice to treat temporomandibular disorders. In TMD patients, evidences have shown efficacy in increasing temporomandibular joint movement amplitude, accelerating serotonin, encephalin and endorphin release, thus favoring masticatory muscles relaxation and pain relief. According to recent articles, most commonly used points for this purpose are: ST6, ST7, SJ21, SJ17, SI18, Taiyaing and Yintang (face and head) and LI4 (extrafacial). CONCLUSION: Acupuncture is as effective to control facial pain as conventional Western therapies. It is considered useful, of low cost and provides better quality of life to patients treated with this technique.

Keywords: Acupuncture analgesia, Facial pain, Temporomandibular joint disorders.

\footnotetext{
1. Universidade de Araraquara, Faculdade de Odontologia, Araraquara, SP, Brasil.

Submitted in April 26, 2016.

Acceoted fir publication in August 08, 2016

Conflict of interests: none - Sponsoring sources: none.

Endereço para correspondência:

Faculdade de Odontologia da Universidade de Araraquara - UNIARA (Unidade IV)

Av. Maria Antonia Camargo de Oliveira, n. 170, Vila Suconasa

14807-120 Araraquara, SP, Brasil.

E-mail: analu.franco@hotmail.com

(C) Sociedade Brasileira para o Estudo da Dor
}

\section{RESUMO}

JUSTIFICATIVA E OBJETIVOS: A disfunção temporomandibular é definida como um conjunto de problemas clínicos que envolvem os músculos mastigatórios, a articulação temporomandibular e estruturas associadas. Por serem de causa multifatorial, diversas modalidades de tratamento são propostas e utilizadas com êxito. Contudo, as terapias mais recomendadas são as reversíveis e nấo invasivas, as quais devem ser a primeira opçáo de escolha no tratamento das disfunçôes temporomandibulares. O objetivo deste estudo foi discorrer sobre o uso da acupuntura no tratamento da disfunção temporomandibular e sintomas associados.

CONTEÚDO: Compuseram essa revisão 34 artigos, publicados entre os anos de 1983 e 2015. Uma vez que a acupuntura busca devolver o equilíbrio do organismo e harmonia entre as partes física e psíquica por meio de estímulos em pontos específicos, pode ser considerada uma terapia de eleição para o tratamento da disfunçáo temporomandibular. Em pacientes com disfunção temporomandibular evidências demonstraram eficácia no aumento da amplitude de movimento da articulação temporomandibular, acelerando a liberaçáo de serotonina, encefalina e endorfina, e favorecendo assim o relaxamento dos músculos mastigatórios e a redução da dor. Segundo os artigos recentes, os pontos mais comumente empregados para esse fim são: E6, E7, TA21, TA17, ID18, Taiyaing e Yintang (face e cabeça) e IG4 (extrafacial).

CONCLUSÁO: A acupuntura tem se mostrado táo eficiente no controle de dores faciais quanto as terapias ocidentais convencionais. É uma terapia considerada útil, de baixo custo e que proporciona uma melhor qualidade de vida aos pacientes tratados com essa técnica.

Descritores: Analgesia por acupuntura, Dor facial, Transtornos da articulação temporomandibular.

\section{INTRODUCTION}

According to the American Academy of Orofacial Pain $(\mathrm{AAOP})^{1}$, temporomandibular disorder (TMD) is a set of clinical signs and symptoms involving masticatory muscles, temporomandibular joint (TMJ) and associated structures. Currently, TMD are basically divided in two major groups, which are joint disorders and masticatory muscles disorders ${ }^{2}$. Most frequently reported symptoms by patients are muscle fatigue, pain on face, TMJ and/or masticatory muscles, headache and earache and jaw movements limitation and/ 
or shifts ${ }^{2}$. It has multifactorial etiology basically summarized as high psychological stress and pain amplification states, together with a wide range of specific risk factors ${ }^{3}$.

Literature data have shown high incidence of TMD in general population, varying from 21.5 to $51.8 \%$. It affects all age groups, although its highest incidence is between 20 and 45 years of age. From 15 to 30 years of age, most frequent causes are of muscle origin and, as from 40 years of age of joint origin. Females are more affected than males, in a proportion of five females for each male ${ }^{4-9}$. Approximately 3.6 to $7 \%$ of the population have sufficiently severe TMD to look for medical assistence ${ }^{1}$.

Reversible and noninvasive therapies are the most recommended to treat TMD and should be the first choice ${ }^{10}$. Among these techniques, one should stress acupuncture ${ }^{10-17}$. Due to its recent use in dentistry, its noninvasive character and effective results, it has been successfully used for this purpose $^{14,16,18-24}$.

Acupuncture is a millenary technique of Traditional Chinese Medicine (TCM) which has been justified and structured on philosophical, rather than scientific basis ${ }^{25}$. The word has Latin etymology $($ acus $=$ needle and puncture $=$ prick $)$ and means needles insertion on specific skin points, called acupoints or acupuncture points, aiming at healing and preventing diseases ${ }^{26-28}$. Acupuncture aims at developing body balance by intervening in the physical body to help reestablishing lost harmony between physical and psychic parts ${ }^{25}$.

Literature suggests that, in TMD patients, acupuncture speeds serotonin, encephalin and endorphin release, being effective to increase jaw movement amplitude and oral function, decreasing muscle hyperactivity, favoring masticatory muscles relaxation, thus decreasing pain ${ }^{24}$. Acupuncture is no longer considered an alternative method, but rather it started to be a treatment alternative without major adverse effects for using own body substances to control pain ${ }^{14}$.

In face of the topicality of the subject, we propose a literature review on acupuncture indications, action mechanism and possible side-effects, when used to treat TMD and associated symptoms.

\section{CONTENTS}

An exploratory search was carried out in Pubmed, Scielo and LILACS databases. Several books and articles were selected, published between 1983 and 2015, on the efficacy of acupuncture for TMD. Descriptors were "acupuncture analgesia", "temporomandibular joint dysfunction syndrome" and "facial pain", in addition to their equivalent in Portuguese, "analgesia por acupunctura", "transtornos da articulação temporomandibular" and "dor facial". In total, 34 articles were selected for matching the objectives of our study, being these narrative reviews and systematic reviews, case reports and clinical trials.

Acupuncture uses individuals' bioenergetic balance, promoting sensation of wellbeing (endogenous opioids release) and dramatically decreasing muscle tension points and/or trigger-points, frequent in TMD patients ${ }^{29}$. So, it is important tool to manage patients with joint ${ }^{16}$ and muscle ${ }^{24}$ disorders, with good clinical results ${ }^{24,30,31}$.

According to the principles of the technique, needle entrance in skin causes micro-inflammation which moves natural serotonin, encephalin and endorphin production. The release of these neurotransmitters blocks painful stimuli propagation, impairing its perception by the brain. So, body response is faster, decreasing symptoms intensity, often making them disappear. Acupuncture stimulates blood circulation dynamics due to regional microdilation and relaxation; it releases hormones, such as cortisol and endorphins; increases host resistance by means of stimulating hypothalamus, hypophysis and other important glands for systemic recovery; it normalizes body functions and stimulates metabolism of different organ $s^{24,28}$.

So, it is characterized as potent analgesic, sedative and relaxant, which is the basis for its application in dental treatments $^{32}$. It may be indicated as first treatment option when patients are allergic or suffer severe adverse effects induced by drugs, in cases of liver or kidney function failure, history of gastric bleeding when using anti-inflammatory drugs, or for the elderly needing many drugs $s^{29,32}$. For having few adverse effects, it provides further safety for hypertensive, diabetic, cardiac and hemophilic patients, children, pregnant women and those affected by human immunodeficiency virus (HIV) ${ }^{29}$. It is an effective and economic method, causes few clinically relevant adverse effects and may promote decreased salivation, nausea and postoperative pain, by regulating homeostasis and immunodefensive and antiinflammatory responses ${ }^{32}$. Acupuncture adverse effects are minimal, being in general associated to dizziness, nausea and, in some cases, transient erythema or increased pain in the first hours ${ }^{26}$.

In dentistry, acupuncture is effective to treat orofacial pains, such as idiopathic trigeminal neuralgias, herpes-zoster, maxillary sinusitis, toothache, TMJ arthritis, as well as in patients with dry mouth, bruxism and $\mathrm{TMD}^{29}$. It may be indicated for pre-treatment of anxious, stressed or hypertensive patients or with systemic diseases, and to improve assistance quality since it is able to induce analgesia in Endodontics, Periodontics and Surgical procedures ${ }^{33}$. Acupuncture has been indicated to treat chronic facial pain resistant to conventional treatments (occlusal splint or physical jaw exercises), especially in cases of muscle pain. Some selected studies have compared the efficacy of occlusal splint and acupuncture.

Both therapies resulted in significant improvement of subjective symptoms and clinical signs in the stomatognatic system, with significant pain decrease in all evaluation variables, during 12 months of study ${ }^{11,13,33}$. Another study has shown that, for patients under anti-inflammatory drugs to control orofacial pain, TCM was effective to decrease drug use ${ }^{34}$.

Most studies involving acupuncture as therapeutic method were carried out with female samples, due to the high prevalence of TMD in this gender ${ }^{16,33,35,36}$. With samples in mean 
age group between 20 and 40 years, results have shown that treatment efficacy is not influenced by age, but rather by pain intensity and number of sessions to be performed ${ }^{17}$. However, it is important to stress that different studies based on TCM principles, have not evaluated TMD alone, but rather the body as a whole, posture and general health among other aspects, before determining the adequate therapy.

Different protocols regarding acupuncture points used for TMD, type of stimulation, number of sessions and intervals between them are described in the literature. Since application sites and number of sessions change from individual to individual and depend on the origin of the problem, it is difficult to compare protocols and results of different studies. However, some authors ${ }^{14,15}$ mention average of 6-8 sessions lasting 30 minutes each to obtain effective results of TMD treatment by acupuncture and, although there are reports of improvement in the first session, pain relief is seen in the medium term with consequent jaw function improvement ${ }^{16,17}$.

Treatment duration may vary in a case-by-case basis and for the same disease, because one has to take into account whether it is acute or chronic disease and even different individual responses to treatment with acupuncture. In chronic conditions, during acupuncture treatment, symptoms are expected to improve as from the fourth session although each individual responds differently. In acute processes, results are fast with few applications, but in chronic processes they may require months of treatment. In cases of extreme pain, improvement might be immediate, being that as from the second session treatment may be once a week in a total of six sessions and may continue for three months until symptoms remission ${ }^{17}$. Some more recent studies evaluating the effects of acupuncture in $\operatorname{TMD}^{16,22-24,31,34,35,38}$, and published in the last five years, are described in table 1.

There is no standard clinical protocol to select points used in each treatment. Differently from Western therapies, acupuncture is applied based on biopsychosocial data collected by TCM during patients' anamnesis, that is, all protocols should be tailored according to each patient's needs. However, this is not possible in most clinical trials, as shown by the literature ${ }^{24}$. As shown in table 1 , some studies use special protocols and others use fixed protocols. According to

Table 1. Summary of more recent studies (last five years) on temporomandibular disorder treatment with acupuncture

\begin{tabular}{|c|c|c|c|c|c|}
\hline Authors & $\begin{array}{l}\text { Type of } \\
\text { study }\end{array}$ & Sample & Recommended points & $\begin{array}{l}\text { Number of ses- } \\
\text { sions and treat- } \\
\text { ment duration }\end{array}$ & Primary results \\
\hline $\begin{array}{l}\text { Borin } \\
\text { et al. }{ }^{16}\end{array}$ & Clinical trial & $\begin{array}{l}40 \text { females, } \\
20 \text { received acu- } \\
\text { puncture and } 20 \text { have } \\
\text { not received }\end{array}$ & $\begin{array}{l}\text { Fixed protocol: ST7, ST5, SJ17, GB3, } \\
\text { taiyang and yintang (face) and GB43 } \\
\text { (extrafacial) }\end{array}$ & $\begin{array}{l}\text { Twice a week for } 5 \\
\text { weeks }\end{array}$ & $\begin{array}{l}\text { Improved TMD severity and } \\
\text { decreased pain level }\end{array}$ \\
\hline $\begin{array}{l}\text { Borin } \\
\text { et al. }{ }^{35}\end{array}$ & Clinical trial & $\begin{array}{l}40 \text { females, } \\
20 \text { received acu- } \\
\text { puncture and } 20 \text { have } \\
\text { not received }\end{array}$ & $\begin{array}{l}\text { Fixed protocol: ST7, ST5, TE17, GB3, } \\
\text { taiyang and yintang (face) and GB43 } \\
\text { (extrafacial) }\end{array}$ & $\begin{array}{l}\text { Twice a week for } 5 \\
\text { weeks }\end{array}$ & $\begin{array}{l}\text { Decreased temporal mus- } \\
\text { cle electric activity, promo- } \\
\text { ting better balance betwe- } \\
\text { en masseter and temporal } \\
\text { muscles }\end{array}$ \\
\hline $\begin{array}{l}\text { Elder et } \\
\text { al. }^{34}\end{array}$ & Clinical trial & $\begin{array}{l}111 \text { patients, recei- } \\
\text { ved acupuncture and } \\
\text { orientations about } \\
\text { TMD }\end{array}$ & $\begin{array}{l}\text { Fixed protocol ST6, ST7, SI18, (face), } \\
\text { VG20, GB20, SP10 (head) and LI4 (ex- } \\
\text { trafacial) in addition to specific points } \\
\text { by diagnosis, not exceeding } 20 \text { points. }\end{array}$ & $\begin{array}{l}\text { Mean of } 20 \text { ses- } \\
\text { sions during one } \\
\text { year }\end{array}$ & $\begin{array}{l}\text { TMD pain was linearly decre- } \\
\text { ased after mean period of } 16 \\
\text { sessions and decreased use } \\
\text { of anti-inflammatory drugs } \\
\text { among frequent users }\end{array}$ \\
\hline $\begin{array}{l}\text { Vicente- } \\
\text {-Barrero } \\
\text { et al. }{ }^{31}\end{array}$ & Clinical trial & $\begin{array}{l}20 \text { patients, } 10 \text { trea- } \\
\text { ted with acupuncture } \\
\text { and } 10 \text { with occlusal } \\
\text { splint }\end{array}$ & $\begin{array}{l}\text { Fixed protocol: } \\
\text { Extra Taiyang, SJ21, GB2, SJ17, ST6 } \\
\text { (face and head), LI4, ST36, SJ5 and } \\
\text { GB34. }\end{array}$ & $\begin{array}{l}15 \text { sessions, } 3 \\
\text { consecutive and } \\
\text { others } 3 x \text { a week. }\end{array}$ & $\begin{array}{l}\text { Acupuncture group had sig- } \\
\text { nificant improvement in all } \\
\text { evaluated parameters }\end{array}$ \\
\hline $\begin{array}{l}\text { Sousa } \\
\text { et al. }{ }^{22}\end{array}$ & Clinical trial & 20 patients & Specific points by diagnosis & $\begin{array}{l}8 \text { sessions, once a } \\
\text { week }\end{array}$ & $\begin{array}{l}\text { Pain decrease, maintained } \\
\text { for one year }\end{array}$ \\
\hline $\begin{array}{l}\text { Jung } \\
\text { et al. }^{38}\end{array}$ & $\begin{array}{l}\text { Systematic } \\
\text { review }\end{array}$ & $\begin{array}{l}7 \text { controlled and ran- } \\
\text { domized studies }\end{array}$ & LI4, ST6, SI18, SI2, SI3 and ST7 & 1 to 3 weeks & $\begin{array}{l}\text { Limited evidence of acu- } \\
\text { puncture to treat TMD }\end{array}$ \\
\hline
\end{tabular}


Table 2. Location and function of most commonly used acupoints to treat temporomandibular disorder ${ }^{37}$

\begin{tabular}{|c|c|c|}
\hline Point & Location & Function \\
\hline ST6 & Prominence of masseter muscle & $\begin{array}{l}\text { Relaxes facial muscles and improves temporomandibular } \\
\text { joint Qi }\end{array}$ \\
\hline ST7 & $\begin{array}{l}\text { In the Center of depression between jaw notch and zygomatic arch } \\
\text { inferior border }\end{array}$ & Improves TMJ functions and relieves spasms and pain \\
\hline SJ17 & Point where ear lobe touches the neck & Relaxes tendons and muscles \\
\hline SJ 21 & Interosseous cavity before tragus and above condyle & Treats temporomandibular pain and arthritis and jaw pain \\
\hline SI18 & Inferior zygomatic arch border, anterior masseter muscle border & $\begin{array}{l}\text { Relieves pain, calms the mind, treats facial pain and facial } \\
\text { nerve spasm. }\end{array}$ \\
\hline Taiyang & Between lateral eyebrow edge and lateral eyes epicanthus & Calms pain, treats facial muscle spasm \\
\hline Yintang & Face midline between eyebrows & Interrupts pain, calms the mind, treats headache \\
\hline LI4 & Between metacarpi I and II in muscle bulge & $\begin{array}{l}\text { Treats headaches, facial pains, trismus, head and neck an- } \\
\text { esthesia }\end{array}$ \\
\hline
\end{tabular}

TMJ = temporomandibular joint.

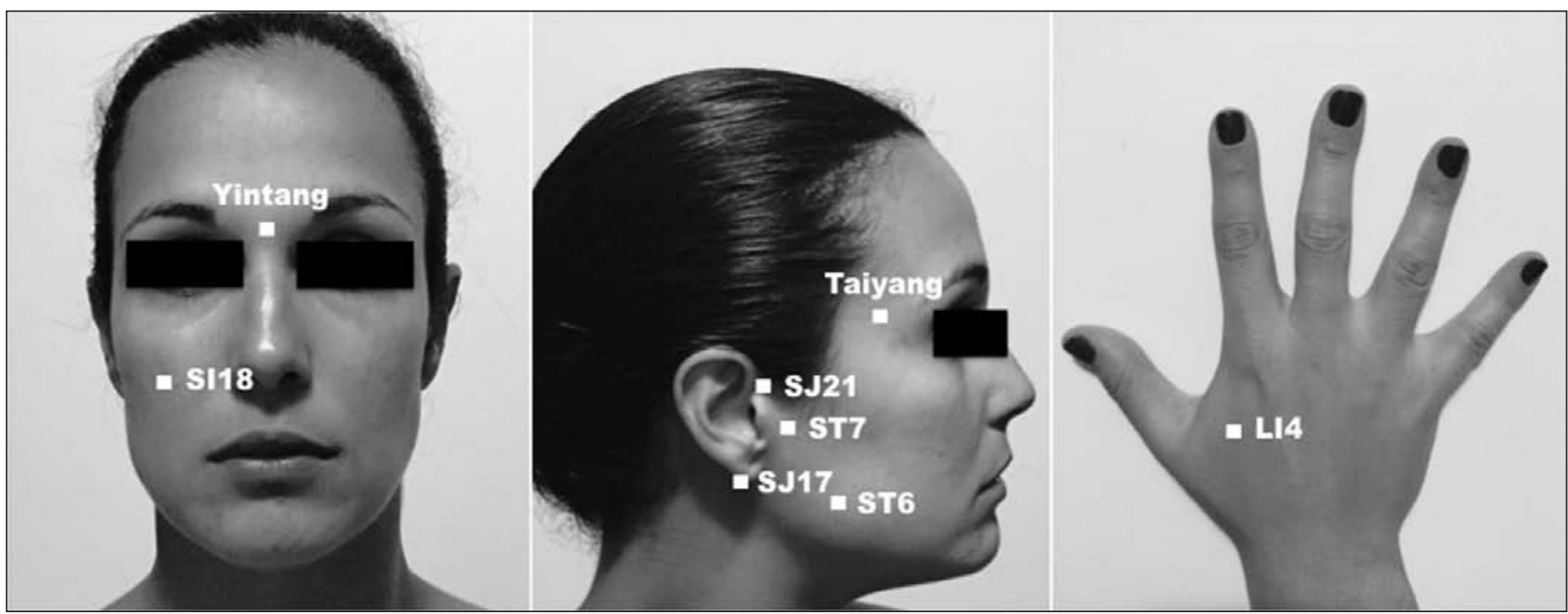

Figure 1. Location of commonly used acupoints to treat temporomandibular disorders ${ }^{37}$

recent studies, most commonly used points in protocols to treat TMD-induced facial pain and associated symptoms are ST6, ST7, SJ21, SJ17, SI18, Taiyaing and Yintang (face and head) and LI4 (extrafacial) (Table 2, Figure 1) 16,22-24,31,34,35,38. Notwithstanding promising acupuncture results, a systematic review has shown that there are still controversies and limitations to the effectiveness of acupuncture to treat $\mathrm{TMD}^{38}$, which suggests that studies in the area shall continue for the definition of better treatment protocols and to measure the real efficacy of the technique as compared to most traditional modalities to treat TMD.

\section{CONCLUSION}

Acupuncture has been shown to be effective to control facial pain, especially pain of muscular origin. For having low incidence of side effects, its use may be continuous, being an excellent option to control or treat pain and TMD.

\section{REFERENCES}

1. American Academy of Orofacial Pain. General assessment of the orofacial pain patient. In: de Leeuw R, Klasser GD, editors. Orofacial pain - guidelines for assessment, diagnosis and management. 5th ed. Chicago: Quintessence; 2013. 25-46p.

2. Peck CC, Goulet JP, Lobbezoo F, Schiffman EL, Alstergren P, Anderson GC, et al. Expanding the taxonomy of the diagnostic criteria for temporomandibular disorders. J Oral Rehabil. 2014;41(1):2-23.

3. Maixner W, Diatchenko L, Dubner R, Fillingim RB, Greenspan JD, Knott C, et al. Orofacial pain prospective evaluation and risk assessment study--the OPPERA study. J Pain. 2011;12(11 Suppl):T4-11.e1-2.

4. Moss RA, Garrett JC. Temporomandibular joint dysfunction syndrome and myofascial pain dysfunction syndrome: a critical review. J Oral Rehabil. 1984;11(1):3-28.

5. De Kanter RJ, Truin GJ, Burgersdijk RC, Van 't Hof MA, Battistuzzi PG, Kalsbeek $\mathrm{H}$, et al. Prevalence in the Dutch adult population and a meta-analysis of signs and symptoms of temporomandibular disorder. J Dent Res. 1993;72(11):1509-18.

6. Drangsholt M, LeResche L. Temporomandibular Disorder Pain. In: Crombie IK, Croft PR, Linton SJ, LeResche L, Von Korff M, editors. Epidemiology of pain. Seattle: IASP Press; 1999. 203-33p.

7. Dworkin SF, Huggins KH, LeResche L, Von Korff M, Howard J, Truelove E, et al Epidemiology of signs and symptoms in temporomandibular disorders: clinical signs in cases and controls. J Am Dent Assoc. 1990;120(3):273-81.

8. Gesch D, Bernhardt O, Alte D, Schwahn C, Kocher T, John U, et al. Prevalence of signs and symptoms of temporomandibular disorders in an urban and rural German population: results of a population-based Study of Health in Pomerania. Quintessence 
Int. 2004;35(2):143-50

9. Gonçalves DA, Dal Fabbro AL, Campos JA, Bigal ME, Speciali JG. Symptoms of temporomandibular disorders in the population: an epidemiological study. J Orofac Pain. 2010;24(3):270-8.

10. Okeson JP, Moody PM, Kemper JT, Haley JV. Evaluation of occlusal splint therapy and relaxation procedures in patients with temporomandibular disorders. J Am Dent Assoc. 1983;107(3):420-4.

11. List T, Helkimo M. Acupuncture and occlusal splint therapy in the treatment of craniomandibular disorders. II. A 1-year follow-up study. Acta Odontol Scand. 1992;50(6):375-85.

12. MacPherson H, White A, Cummings M, Jobst KA, Rose K, Niemtzow RC. Standards for reporting interventions in controlled trials of acupuncture: the STRICTA recommendations. J Altern Complement Med. 2002;8(1):85-9.

13. 13.Johansson A, Wenneberg B, Wagersten C, Haraldson T. Acupuncture in treatment of facial muscular pain. Acta Odontol Scand. 1991;49(3):153-8.

14. Branco CA, Fonseca RB, Oliveira TR, Gomes VL, Alfredo Júlio, Fernandes Neto AJ. Acupuntura como tratamento complementar nas disfunçōes temporomandibulares: revisão da literatura. Rev Odontol UNESP. 2005;34(1):11-6.

15. Quaggio AM,Carvalho PS,Santos JFF, Marchini L. A utilização da acupuntura em desordens craniomandibulares. JBA. 2002;2(8):334-7.

16. Borin GS, Corrêa EC, Silva AMT, Milanesi JM. Acupuntura como recurso terapêutico na dor e na gravidade da desordem temporomandibular. Fisioter Pesqui. 2011;18(3):217-22.

17. Meirelles MP, Gonçalo CS, Sousa MLR. Manejo da dor orofacial através do tratamento com acupuntura: relato de um caso. Rev Odontol UNESP. 2009;38(6):379-82.

18. Zotelli VL, Meirelles MP, Sousa ML. Uso da acupuntura no manejo da dor em pacientes com alteraçóes na articulaçẫo temporomandibular. Rev Odontol UNICID. 2010;22(2):185-8.

19. Florian MR, Meirelles MP, Sousa ML. Disfunçáo temporomandibular e acupuntura: uma terapia integrativa e complementar. Odontol Clin-Cient. 2011;10(2):189-92.

20. Rui A, Meirelles MP, Sousa ML. Relato de caso sobre o uso da acupuntura no tratamento da dor orofacial. Arq Ciênc Saúde UNIPAR. 2011;15(3):287-90.

21. Vera RM, Grillo CM, Fortinguerra ML, Sousa ML, Berzin F. Acupuntura no manuseio da dor orofacial e do tinido. Relato de caso. Rev Dor. 2013;14(3):226-30.

22. Sousa ML, Mashuda CS, Sato JE, Siqueira JT. Effects of acupuncture in adults with temporomandibular disorders. Rev Dor. 2014;15(2):87-90.

23. Camargo BA, Grillo CM, Sousa ML. Temporomandibular disorder pain improvement with acupuncture: preliminar longitudinal descriptive study. Rev Dor. 2014;15(3):159-62

24. Porporatti AL, Costa YM, Stuginsky-Barbosa J, Bonjardim LR, Conti PC. Acupunc- ture therapeutic protocols for the management of temporomandibular disorders. Rev Dor. $2015 ; 16(1): 53-9$.

25. Silva DF. Psicologia e acupuntura: aspectos históricos, políticos e teóricos. Psicologia Ciência e Profissão. 2007;27(3):418-29.

26. Magro KO, Hirschfeld GC, Campolongo GD, Barros TE. Acupuntura: tratamento alternativo nas dores orofaciais. Unidor - Unidade de Dor e Deformidade Orofacial [Acesso em 15 ago 2010]. Disponível em: <http://www.unidor.com.br/publi/Acupuntura_DOF.pdf>.

27. Rosted P. Introduction to acupuncture in dentistry. Br Dent J. 2000;189(2):136-40.

28. Wen, Tom Sintan. Acupuntura clássica chinesa. 2a Ed. São Paulo: Cultrix; 2014.

29. Vianna RS, Souza AG, Silva BC, Berlinck TA, Dias KR. A acupuntura e sua aplicação na odontologia. UFES Rev Odontol. 2008;10(4):48-52.

30. Ritenbaugh C, Hammerschlag R, Dworkin SF, Aickin MG, Mist SD, Elder C, et al. Comparative Effectiveness of Traditional Chinese Medicine (TCM) and Psychosocial Care in the Treatment of TMD-associated Chronic Facial Pain. J Pain. 2012;13(11):1075-89.

31. Vicente-Barrero M, Yu-Lu SL, Zhang B, Bocanegra-Pérez S, Durán-Moreno D, López-Márquez A, et al. Efficacy of acupuncture and decompression splints in the treatment of temporomandibular joint pain-dysfunction syndrome. Med Oral Patol Oral Cir Bucal. 2012;17(6):1028-33.

32. Navarro ME, Alayón AT, Herrera ME, Fernández RD. La acupuntura y su aplicación em estomatologia. Rev Cubana Estomatol. 2012;26(2):158-66.

33. Rezende MC, Sant'Anna CB, Aguiar SM, Bertoz AP, Hall KB, Dyonisio AL, et al. Temporomandibular disorders in females: acupuncture compared to occlusal splint. Arch Health Invest. 2013;2(3):8-14.

34. Elder C, Ritenbaugh C, Aickin M, Hammerschlag R, Dworkin S, Mist S, et al. Reductions in pain medication use associated with tradicional Chinese medicine for chronic pain. Perm J. 2012;16(3):18-23.

35. Borin GS, Corrêa EC, Silva AM, Milanes JM. Avaliaçẫo eletromiográfica dos músculos da mastigaçáo de indivíduos com desordem temporomandibular submetidos a acupuntura. Rev Soc Bras Fonoaudiol. 2012;17(1):1-8.

36. Hotta PT, Hotta TH, Betaglion C, Bataglion SA, de Souza Coronatto EA, Siéssere $S$, et al. Emg analysis after laser acupuncture in patients with temporomandibular dysfunction (TMD). Implications for practice. Complement Ther Clin Pract. 2010;6(3):158-60.

37. Martins EIS. Atlas dos pontos de acupuntura: guia de localização. Săo Paulo: Rocca, 2011. 884 p.

38. Jung A, Shin BC, Lee MS, Sim H, Ernst E. Acupuncture for treating temporomandibular joint disorders: A systematic review and meta-analysis of randomized, shamcontrolled trials. J Dent. 2011;39(5):341-50. 